preserve and enhance national educational traditions.

Keywords: Higher Education, institution of higher education (IHE), autonomy, academic mobility, academic freedom, the quality of higher education, the quality of educational activities, European Higher Education Area (E HEA).

DOI: https://doi.org/10.31392/NZ-npu-142.2019.21

УДК 378.011.3-051:78:37.041

Пань Цяны

\title{
СИТУАЦІЇ ВИБОРУ ЯК ЗАСІБ РОЗВИТКУ КРЕАТИВНОСТІ УЧНІВ ПІДЛІТКОВОГО ВІКУ У НАВЧАЛЬНО-МУЗИЧНІЙ ДІЯЛЬНОСТІ
}

У статті розглянуто найважливіший педагогічний засіб розвитку креативності підлітків, ̈̈х активності, самостійності та індивідуальності, яким виступає спеціально спроектована ситуачія вибору в навчально-музичній діяльності, використання якої ставить школярів в умови, пов'язані з необхідністю віддати перевагу одному з варіантів, здійснити самостійний усвідомлений, адекватний $і$ значимий вибір. Автор статті пропонує й мотивує ситуації реального вибору; ситуації вибору навчальних завдань різного рівня; ситуачії вибору за певними критеріями; ситуації вибору навчальної мети, яка диференціюється за ступенем спрямованості; ситуації вибору за мотивацією досягнення мети. Простежено зв'язок між розвитком креативних якостей особистості учнів підліткового віку $i$ ситуацією вибору в навчально-музичній діяльності; виявлено потенщіал використання ситуації вибору як засобу розвитку креативності підлітків.

Розглянуто здатність до самостійної творчої діяльності і націленість на ї̈ результат, щзо сприяє підвищенню рівня креативності, представляє собою інтегровану якість особистості, в якій сфери психіки, властивості і якості учня пов'язані між собою.

До засобів, щуо активно впливають на розвиток креативності підлітків, належить ситуачія вибору в навчально-музичній діяльності, яка виникає в результаті зіткнення різних поглядів, використання завдань з багатьма даними або вибору з декількох способів найбільш рачіональних. Під ситуачією вибору розуміється сукупність обставин зовнішнього світу $i$ внутрішнього стану людини, на тлі якого актуалізується необхідність пошуку $і$ переваги однієї з прихованих або явних альтернатив.

Рімення завдань з неповними даними штовхає учнів на шлях самостійності добування знань, а постановка завдань із зайвими даними ставить їх перед проблемою вибору $і$ оцінки знань, активізуючи тим самим ӥх пошукову діяльність.

Ключові слова: ситуачії вибору, креативність, навчально-музична діяльність, освітній процес, вчитель музики, учні підліткового віку.

Загальноприйняте розуміння освіти, як засвоєння людиною досвіду минулого, набуває сьогодні протиріччя 3 його потребою у творчій самореалізації учнів. Здатність до творчості, що закладена в людині споконвічно, виражається в його прагненні до відкриття і створення нового в різних сферах життєдіяльності. Сучасній людині необхідно навчитися осмислено, грамотно і продуктивно діяти в нестандартних ситуаціях. У зв'язку з 
цим перед загальноосвітньою школою постає завдання формування творчої особистості. Актуальність проблеми вибору ефективних засобів розвитку креативності (загальної здібності до творчості) школярів пов'язана, перш за все, з пошуком шляхів інтенсифікації навчально-музичної та творчої діяльності в колективній та індивідуальній формах.

Застосування проблемних ситуацій у творчій діяльності школярів розкривається в роботах Г. Балла, І. Лернера, М. Матюшкина, М. Махмутова, М. Скаткина, Т. Шамової. Вчені звернули увагу, що, незважаючи на природну здатність до творчості, людина може реалізувати її на різних рівнях, але лише цілеспрямоване навчання надає можливості забезпечити високий рівень розвитку закладених творчих здібностей. Підкреслюється, що стимулювати креативні здібності в процесі навчання можуть тільки завдання "відкритого" типу, які передбачають повну самостійність у виборі способу вирішення та велику кількість відповідей.

Особливості підліткового віку визначаються конкретними соціальними обставинами, насамперед - зміною місця дитини в суспільстві, зміною її позиції при вступі в нові відносини зі світом дорослих, світом їх цінностей, що визначає новий зміст ії свідомості. Вважаємо, що підлітковий вік, створює певні передумови для успішного розвитку соціальної креативності і лідерських здібностей.

Проблему формування здібностей школярів до творчої музичної діяльності вивчали психологи (Б. Ананьєв, Л. Виготський, Є.Голубєва, Г. Костюк, Б. Теплов та ін.), музикознавці (Б. Асаф'єв, Л. Баренбойм, В. Медушевський, Є. Назайкінський, Б.Яворський та ін.), педагоги (В. Верховинець, Н. Ветлугіна, О. Лобова, Л. Масол, Г. Падалка, Є. Печерська, О. Ростовський та ін.). Вченими доведено, що вирішення проблеми музичного розвитку дітей та їх креативності досягається через активну діяльність і пробудження природної емоційної чутливості. У навчальній діяльності елементи творчості учнів проявляються, насамперед, в особливостях її перебігу, зокрема, в умінні бачити проблему, знаходити нові способи вирішення конкретно-практичних і навчальних завдань у нестандартних ситуаціях.

Отже, найважливішим педагогічним засобом розвитку креативності підлітків, їх активності, самостійності та індивідуальності виступає спеціально спроектована ситуація вибору в навчально-музичній діяльності, використання якої ставить школярів в умови, пов'язані з необхідністю віддати свою перевагу одному 3 варіантів, здійснити самостійний усвідомлений, адекватний і значимий вибір.

Mema cmammi - обґрунтувати використання ситуації вибору як ефективного засобу формування креативності підлітків в навчально-музичній діяльності.

До засобів, що активно впливають на розвиток креативності підлітків, належить ситуація вибору в навчально-музичній діяльності, яка виникає в результаті зіткнення різних поглядів, використання завдань з багатьма даними або вибору з декількох способів найбільш раціональних.

У науковій літературі під ситуацією вибору розуміється сукупність обставин зовнішнього світу і внутрішнього стану людини, на тлі якого актуалізується необхідність пошуку і переваги однієї з прихованих або 
явних альтернатив [3].

3 утвердженням в педагогічній науці пріоритету гуманістичної парадигми, яка характеризується, перш за все, особистісно-орієнтованою спрямованістю на фрормування творчого компонента в структурі особистості учня, стало можливим використання потенціалу ситуації вибору в повній мірі. Потенціал ситуації вибору в навчанні розкриває зміст ситуації, сукупність можливостей і засобів, укладених в ній і необхідних для розвитку креативності школярів підліткового віку. Ідея вільного вибору становить сутність педагогіки співробітництва, підлітку необхідно надати можливість вибору і вчити його здійснювати обґрунтований вибір.

Ситуація вибору в педагогіці - це конкретний "педагогічний" тип проблемної ситуації, можливість створення якої забезпечується тим, що той, хто навчається ставиться перед різноманіттям вибору з наявних систем знань тієї єдино необхідної системи, використання якої може забезпечити правильне рішення завдання (Ш. Амонашвілі, Л. Байбородова, О. Воскрекасенка, С. Зайцев, Е. Зауторова, А. Карпов, О. Кірєєва, Н. Колизаева, М.Лук'янова, Т. Машарова, Е. Руденко, Л. Чубарова, 3. Яковлєва та ін.).

Рішення завдань 3 неповними даними штовхає учнів на шлях самостійності добування знань, а постановка завдань з зайвими даними ставить їх перед проблемою вибору і оцінки знань, активізуючи тим самим їх пошукову діяльність. При цьому не варто допускати безмежного і неконтрольованого вибору, він має здійснюватися в доцільних межах.

Ситуація вибору виникає в результаті зіткнення різних поглядів, використання завдань з надлишковими даними або вибору з декількох способів найбільш раціональних. При їі створенні виникає необхідність організації умов для вільного вибору, який в свою чергу виступає як умова розвитку креативності. Ситуація вибору дає змогу створювати середу для самоствердження і самоактуалізації учнів підліткового віку, виховувати вольові якості, використовувати діалогові та ігрові форми.

На стадії організації ситуації вибору необхідно взяти до уваги факт створення стану інтелектуального утруднення в учнів, викликане, 3 одного боку, гострим бажанням вирішити проблему, 3 другого усвідомленням неможливості зробити це без додаткових знань і 3 допомогою вже знайомих способів дій. Виникає потреба в добуванні нових знань і в освоєнні нових дій. Вчитель пропонує шляхом постановки проблемного завдання прийняти рішення в ситуації вибору, суть якої полягає в тому, щоб зробити вибір з наявних вже готових варіантів (часткова пошукова діяльність) або варіанти повинен запропонувати сам учень (самостійна пошукова діяльність). Навчання йде через власний пошук учасників процесу і незалежний вибір можливих альтернатив або їх перетворення.

При проектуванні і побудові ситуації необхідно враховувати 
готовність до вибору, педагогічну доцільність створення ситуації, стимулювання учнів до вибору, аргументації свого вибору, визначення ступеня свободи вибору, захищеність учнів від помилок, оцінку результатів рішення обраного варіанту [1, с. 45]. За допомогою ситуації вибору вчитель планує пошукову діяльність учнів на навчальному матеріалі, готує до реальної самостійної творчості.

Проте позитивне рішення в цій ситуації можливо в тому випадку, якщо підліток вміє справлятися з інтелектуальною напругою, почуттям незадоволеності в своїх навчальних результатах, вміє виявляти вольові якості характеру, тобто бути готовим до вибору.

Ситуація вибору в навчально-музичній діяльності безпосередньо пов'язана з пошуковою діяльністю, в якій креативні якості особистості будуть актуалізовані через власний пошук учня на створення незалежної системи вибору альтернатив. Результатом вибору може стати новий освітній продукт.

У навчально-музичній діяльності доцільно створювати ситуації реального вибору, в яких можуть проявитися різні за спрямованістю мотиви, створювати умови підпорядкування мотивів, їх “боротьби", а саме: вибір при наявних варіантах відповіді (закритий вибір); ситуація вільного (відкритого) вибору без відповідей; вибір декількох різноспрямованих спонукань (супідрядність мотивів 3 конфліктом); ситуація вибору з обмеженнями (дефіцит часу, змагання, різні типи оцінювання іншою людиною); помилковий вибір (пропонується вибір між двома в рівній мірі невірними альтернативами, що відбивають протилежні схильності).

Можливі педагогічні прийоми в ситуаціях реального вибору: вибір навчальних завдань різного рівня (репродуктивних, продуктивних, проблемних); вибір з двох завдань, де в одному варіанті знаходиться кілька способів вирішення завдання; вибір в ситуації 3 обмеженими умовами; вибір із завдань різної складності найбільш вподобаних; вибір ситуації конфлікту між пізнавальними і соціальними мотивами; ситуації етичного морального (ціннісного) вибору.

В. Сластьонін вказує на три основні напрямки розвитку креативності учнів: розвиток інтелектуально-творчих здібностей; формування якостей, притаманних творчій особистості; розвиток спрямованості на творчу діяльність [5, с. 457]. Вчений пропонує використовувати в навчальній діяльності творчі технології (завдання, вправи, етюди), що дають змогу особистості максимально "розкритися", виявити свої потенційні можливості, розвинути найбільш значущі для здійснення творчої навчально-музичної діяльності якості, технології, що сприяють подоланню психологічних бар'єрів, пов'язаних із невпевненістю в собі, своїх силах і можливостях, дають змогу відчути себе вільною особистістю, здатною діяти і творити в будь-який нестандартній ситуації.

Навчальний процес пов'язаний 3 постійним творчим пошуком 
вчителя і учнів, оскільки їм доводиться діяти в умовах, що змінюються, в різноманітних педагогічних ситуаціях, де ситуація вибору представлена у всій її сукупності. По-перше, це ситуації вибору навчального завдання за трьома критеріями: матеріал навчального завдання різниться за ступенем складності (легке - середнє - складне); за фрормою роботи (групове - парне - індивідуальне); за ступенем прояву творчої активності (вправа - проблема). По-друге, ситуації вибору навчальної мети, яка диференціюється за ступенем спрямованості (ближні - далекі, стратегічні - тактичні), за мотивацією досягнення мети. Вибрати завжди легше, ніж створювати, але це вже і $є$ елемент творення мети.

Вибір тем учнями-підлітками визначається ступенем особистої зацікавленості (дуже цікавить, слабкий інтерес, не цікавить зовсім); ступенем суспільного значення (наскільки ця проблема цікавить інших людей: багатьох, більшість, меншість); можливістю отримати по темі додаткову інформацію (легко, середньо, важко); можливістю реального втілення проблеми (як часто в наших умовах виникають подібні ситуації: часто, середньо, рідко); готовністю розробити можливості рішення проблемної ситуації (в якій мірі я зацікавлений докласти свої зусилля для вирішення проблемної ситуації: завдання мене зацікавило, я буду брати участь, тому що беруть участь інші; ситуація мене не цікавить). Ухвалення рішення в проблемній ситуації вибору (вибір найкращого варіанту) пов'язане з незалежним індивідуальним вибором особистості, що не $\epsilon$ простим перебором запропонованих варіантів. Особистість, розвинена в творчому і моральному відношенні, вирішуючи значиму для себе проблему, ніколи не стане вибирати щось із сукупності готових, ззовні нав'язаних альтернатив, що склалися незалежно від неї. Вона вибирає будь-яку з тих альтернатив, в фрормуванні яких сама брала участь, або добудовує і перетворює існуючі альтернативи, або додає до них нові [2].

Під вибором в навчально-музичній діяльності ми розуміємо спеціально спроектовану педагогічну ситуацію, що актуалізує необхідність пошуку і прийняття підлітками самостійного рішення, в процесі якого розвивається їх сприйнятливість до нових ідей, готовність до вибору в нестандартних ситуаціях, рефлексія, оригінальність, здатність до самостійної творчої діяльності і націленість на її результат, що сприяє підвищенню рівня креативності, представляє собою інтегровану якість особистості, в якій сфери психіки, властивості і якості учня пов'язані між собою.

Висновки. Класифіковано ситуації реального вибору; ситуації вибору навчальних завдань різного рівня; ситуації вибору за певними критеріями; ситуації вибору навчальної мети, яка диференціюється за ступенем спрямованості; ситуації вибору за мотивацією досягнення мети. Розглянуто зв'язок між розвитком креативних якостей особистості учнів підліткового віку і ситуацією вибору в навчально-музичній діяльності. Виявлено потенціал найбільш ефективного використання ситуації вибору як засобу розвитку креативності підлітків. 


\section{Використана література:}

1. Колызаева Н. Г. Формирование адаптивных характеристик личности у студентов в начальном периоде обучения : дисс. ... канд. псих. наук. Л., 1989. 243 с.

2. Кудрявцев В. Т. Орудийность и креативность: опыт логико -психологического анализа проблемы (к критике идеи выбора) [Электронный ресурc]. URL: http//tovievich.ru>book/3/126/l.htm.

3. Маклаков А. Г. Личностный адаптационный потенциал: его мобилизация и прогнозирование в экстремальных условиях. Психологический журнал. 2001. № 1. С. 16-24.

4. Сисоєва С. О. Основи педагогічної творчості : підручник для студентів вищих педагогічних навчальних закладів. Київ : Міленіум, 2006. 344 с.

5. Сластенин В. А., Подымова Л. С. Педагогика: Инновационная деятельность. Москва : ИЧП "Издательство Магистр", 1997. 224 с.

6. Яременко Л. А. Креативність та творчість їх спільне та відмінне. Вища освіта України. 2010. № 4. C. 117-123.

\section{Ref erences:}

[1] Kolyzaeva, N.G. (1989). Formirovanie adaptivnyh harakteristik lichnosti u studentov v nachalnom periode obucheni ya : diss. ... kand. psih. nauk. L., $243 \mathrm{~s}$.

[2] Kudryavcev, V. T. Orudijnost i kreativnost: opyt logiko -psihologicheskogo analiza problemy (k kritike idei vybora) [Elektronnyj resurs]. URL: http//tovievich.ru>book/3/126/l.htm.

[3] Maklakov, A.G. (2001). Lichnostnyj adaptacionnyj potencial: ego mobilizaciya i prognozirovanie v ekstremalnyh usl oviyah. Psihologicheskij zhurnal. № 1. S. 16-24.

[4] Sysoieva, S. O. (2006). Osnovy pedahohichnoi tvorchosti : pidruchnyk dlia studentiv vyshchykh pedahohichnykh navchalnykh zakladiv. K yiv : M ilenium, $344 \mathrm{~s}$.

[5] Slastenin, V.A., Podymova L. S. (1997). Pedagogika: Innovacionnaya deyatelnost. M oskva: IChP "Izdatelstvo M agistr", $224 \mathrm{~s}$.

[6] Iaremenko, L. A . (2010). K reatyvnist ta tvorchist yikh spilne ta vidminne. V yshcha osvita U krainy. № 4. S. 117-123.

ПАНЬ ЦАНьИ. Ситуации выбора как средство развития креативности учеников подросткового возраста в учебно-музыкальной деятельности.

В статье рассмотрено важнейтее педагогическое средство развития креативности подростков, их активности, самостоятельности и индивидуальности, которым выступает специально спроектированная ситуачия выбора в учебно-музыкальной деятельности, использование которой ставит школьников в условия, связанные с необходимостью отдать предпочтение одному из вариантов, осуществить самостоятельный осознанный, адекватный и значимый выбор. Автор статьи предлагает и мотивирует ситуащии реального выбора; ситуации выбора учебных задач различного уровня; ситуачии выбора по определенным критериям; ситуации выбора учебной цели, которая дифференцируется по степени направленности; ситуации выбора по мотивации достижения цели. Прослежена связь между развитием креативных качеств личности учащихся подросткового возраста и ситуацией выбора в учебно-музыкальной деятельности; выявлено потенциал использования ситуации выбора как средства развития креативности подростков.

Рассмотрена способность к самостоятельной творческой деятельности и начеленность на ее результат, что способствует повышению уровня креативности, представляет собой интегрированное качество личности, в которой сферы психики, свойства и качества ученика связань между собой. К средствам, что активно влияют на развитие креативности подростков, относится ситуачия выюора в учебно-музыкальной деятельности, которая возникает в результате столкновения различных точек зрения, использования задач с многими данными или выбора из нескольких способов наиболее рациональных. Под ситуащией выбора понимается совокупность обстоятельств внешнего мира и внутреннего состояния человека, на фоне которого актуализируется необходимость поиска и предпочтения одной из скрытых или явных альтернатив. 
Решение задач с неполными данными толкает учеников на путь самостоятельности добывания знаний, а постановка задач с лишними данными ставит их перед проблемой выбора и оценки знаний, активизируя тем самым их поисковую деятельность.

Ключевые слова: ситуачии выбора, креативность, учебно-музыкальная деятельность, образовательный процесс, учитель музыки, ученики подросткового возраста.

PAN TSANYI. Situations of choice as a means of developing creativity adolescent students in teaching and musical activities.

The article discusses the most important pedagogical means of developing adolescents' creativity, their activity, independence and individuality, which is a specially designed situation of choice in teaching and musical activity, the use of which puts students in conditions related to the need to give preference to one of the options to realize an informed and meaningful choice. The author of the article offers and motivates situations of real choice; situations of choosing learning tasks at various levels; situations of choice according to certain criteria; situations of choosing a learning goal, which is differentiated by degree of orientation; situations of choice on the motivation to achieve the goal. The relationship between the development of the creative qualities of the personality of adolescent students and the situation of choice in educational and musical activities is traced; revealed the potential of using the situation of choice as a means of developing adolescent creativity.

The author considers the ability to independent creative activity and focus on its result, which helps to increase the level of creativity, is an integrated personality quality, in which the spheres of the psyche, qualities and qualities of the student are interconnected. The means that actively influence the development of creativity of adolescents include the situation of choice in educational and musical activity, which arises as a result of a clash of different points of view, the use of tasks with many data, or the choice of several most rational methods. The situation of choice is understood as the totality of the circumstances of the external world and the internal state of a person, against the background of which the need for searching and preference for one of the hidden or explicit alternatives is actualized.

Solving problems with incomplete data pushes students on the path to gaining knowledge independently, and setting tasks with extra data puts them before the problem of selecting and evaluating knowledge, thereby activating their search activity.

Keywords: situations of choice, creativity, educational and musical activities, educational process, music teacher, adolescent students.

DOI: https://doi.org/10.31392/NZ-npu-142.2019.22

УДК 37.013 .3

Рідковець Т. Г., Кутас О.Г.

\section{ЙОГОТЕРАПІЯ І АКУПРЕСУРА ЯК АЛЬТЕРНАТИВНІ МЕТОДИКИ В ВІДНОВНОМУ ЛІКУВАННІ ХВОРИХ НА КОКСАРТРОЗ}

У статті представлені результати позитивного впливу його-терапії $i$ акупресури в комплексному відновлювальному лікуванні хворих на коксартроз. Пропонована терапевтична програма була застосована до хворих з початковою стадією первинного коксартрозу $i$ для людей з підвищеним ризиком появи цьього захворювання. До групи ризику відносяться чоловіки $i$ жінки, які займаються розумовою працею і проводять багато часу за письмовим столом або 